\title{
STRATEGI SALES PROMOTION PRICE DISCOUNT DALAM MENDORONG PEMBELIAN IMPULSIF PRODUK JENIS MINUMAN ISOTONIK Di PT. AMERTA INDAH OTSUKA".
}

\author{
Lalu Hendra Maniza \\ Abdul hafiz \\ Amin Saleh \\ Fakultas Ilmu Sosial Dan Ilmu Politik \\ Universitas Muhammadiyah Mataram \\ Manizahendra@gmail.com \\ Abdl.h4fiz@gmail.com \\ Cukup4amin@gmail.com
}

\begin{abstract}
This research is entitled "sales promotion price discount strategy in encouraging impulse buying of isotonic drink products at pt. amerta Indah otsuka" aims to describe the strategy of selling promotion price discounts in encouraging impulsive purchases of isotonic drink products at PT. Amerta Indah Otsuka. In this study, the method used is a qualitative method with a descriptive approach. The informants in this study were consumers who became customers at PT. Amerta Indah Otsuka which is located around East Lombok. Determination of informants using probability sampling technique with simple random sampling, and data collection techniques using interviews, observation, documentation, while data analysis uses data collection, data reduction, data presentation and data inference and presentation. The results showed that the discount variable can encourage an increase in consumer impulse buying at PT. Amerta Indah Otsuka. The discount given is able to increase the sales volume of isotenic drinks at PT. Amerta Indah Otsuka. It means that the sales promotion strategy by using discounts has been successful and is able to attract or influence people's buying interest, Besides the promotion of selling discounts used by PT. Amerta Indah Otsuka must also pay attention to the merchandising of their products because this is also very influential on the consumer's desire to want to shop at PT. Beautiful Amerta Otsuka
\end{abstract}

Keywords: Sales Promotion Price Discount, Encouraging Impulsive Purchases of Isotonic Drinks

\section{STRATEGI SALES PROMOTION PRICE DISCOUNT DALAM MENDORONG PEMBELIAN IMPULSIF PRODUK JENIS MINUMAN ISOTONIK Di PT. AMERTA INDAH OTSUKA".}

\begin{abstract}
ABSTRAK
Penelitian ini berjudul "strategi sales promotion price discount dalam mendorong pembelian impulsif produk jenis minuman isotonik di pt. amerta indah otsuka" mempunyai tujuan untuk menggambarkan strategi seles promotion price discount dalam mendorong pembelian impulsif produk jenis minuman isotonic di PT. Amerta Indah Otsuka. Pada penelitian ini Metode yang di gunakan ialah metode kualitatif dengan pendekatan deskriptif. Adapun informan dalam penelitian ini para konsumen yang menjadi pelanggan di PT. Amerta Indah Otsuka yang berada di sekitar Lombok Timur. Penentuan informan menggunakan tehnik probabilitiy sampling dengan simple random sampling, dan teknik pengumpulan data menggunakan Wawancara, observasi,
\end{abstract}


dokumentasi, sedangkan analisis data menggunakan Pengumpulan Data, reduksi data, penyajian data serta penyimpulan dan penyajian data. Hasil penelitian menunjukan bahwa Variabel discount dapat mendorong peningkatan impulse buying konsumen pada PT. Amerta Indah Otsuka. discount yang diberiakn mampu meningkatkan volume penjulan minuman jenis isotenik pada PT. Amerta Indah Otsuka. Berarti strategi seles promosi dengan menggunakan diskon sudah berhasil dan mampu menarik atau mempengaruhi minat beli masyarakat, Disamping promosi seles diskon yang digunakan pihak PT. Amerta Indah Otsuka harus juga memperhatikan merchandising produknya Karen hal ini juga sangat berpengaruh terhadap keingin konsumen untuk mau berbelanja di PT. Amerta Indah Otsuka

Kata kunci: Sales Promotion Price Discount, Mendorong Pembelian Impulsif Produk Jenis Minuman Isotonik

\section{A. Latar Belakang}

Persaingan dalam dunia bisnis semakin ketat, membuat perusahaanberusaha mencari strategi yang cepat dan tepat dalam memasarkan produknya.Dalam era globalisasi menuntut perusahaan harus mampu bersikap dan bertindak cepat dan tepat dalam menghadapi persaingan dilingkungan bisnis yang bergerak sangat dinamis dan penuh dengan ketidakpastian. Oleh karena itu, setiap perusahaan dituntut bersaing secara kompetitif dalam hal strategi bisnis untuk mencapai tujuan perusahaan serta memahami apa yang terjadi dipasar dan apa yang menjadi keinginan konsumennya

Setiap perusahaan didirikan dengan tujuan tertentu sehingga dapat tetap hidup dan berkembang. Salah satu tujuan perusahaan tersebut adalah meningkatkan tingkat keuntungan atau laba perusahaan. Tingkat keuntungan dapat dipertahankan apabila perusahaan dapat mempertahankan dan meningkatkan penjualannya, salah satunya melalui usaha mencari dan membina pelanggannya. Kegiatan pemasaran merupakan faktor yang sangat penting dan berpengaruh bagi perusahaan untuk itu bagian pemasaran harus mempunyai strategi yang mantap dalam melihat peluang atau kesempatan yang ada, sehingga posisi perusahaan di pasar dapat dipertahankan dan sekaligus dapat ditingkatkan. Strategi pemasaran yang berorientasi padakonsumen merupakan cara terbaik yang dapat dilakukan perusahaan.

Ditengah persaingan usaha, perusahaan harus mampu bersaing dengan memberikan value yang berbeda dimata konsumen dan memperhatikan faktorfaktor yang mempengaruhi keputusan pembelian konsumen agar dapat bertahan di tengah ramainya persaingan dan guna meningkatkan omset penjualan.

Perusahaan harus menentukan strategi dan rancangan pengembangan produk yang dapat memenuhi kebutuhan konsumen dengan melakukan inovasi atau mengikuti perkembangan trend pasar saat ini. Banyak hal yang harus dipersiapkan sebelum menentukan strategi yang tepat bagi perusahaan, salah satu langkah awalnya adalah dengan mengenali perilaku konsumen serta mendapatkan informasi yang terkait dengan perilakunya tersebut.

Dalam usaha mempengaruhi pasar untuk melakukan keputusan pembelian, kegiatan-kegiatan promosi adalah kombinasi strategi yang lebih 
baik, dan seluruhnya direncanakan untuk mencapai tujuan penjualan. Perusahaan dalam hal ini tidak hanya menjual produk, akan tetapi juga harus memahami apa yang diinginkan konsumen sehingga akan berpengaruh terhadap keputusan pembelian pada konsumen.

Setiap perusahaan memiliki strategi masing-masing guna memasarkan produknya, untuk menarik ketertarikan pelanggan. Ketertarikan pelanggan akan produk yang diberikan membuat pelanggan merasa senang dan akhirnya akan loyal kepada produk, sehingga kepercayaan pelanggan terhadap perusahaan akan lebih mudah terbentuk. Hal ini memberikan kemudahan kepada perusahaan untuk menarik pelanggan selanjutnya. Pemasaran produk dari perusahaan dapat melalui berbagai cara antara lain brosur, pamflet, iklan di televisi, dan promosi tertentu pada penjualan produk. Dilihat dari kegiatan pemasaran, pembelian terdiri atas dua macam, yaitu pembelian yang terencana dan pembelian yang tidak direncanakan sebelumnya. Pembelian yang terencana didasarkan pada kebutuhan pelanggan, sedangkan yang tidak terencana (impulse buying) merupakan perilaku pelanggan yang melakukan pembelian tanpa ada rencana sebelumnya.

Menurut Mowen \& Minor (2002) pembelian yang tidak terencana (impulse buying) adalah tindakan membeli yang dilakukan tanpa memiliki masalah sebelumnya atau maksud ata niat membeli yang terbentuk sebelum memasuki toko. Hal yang sama juga diungkapkan oleh Schiffman dan Kanuk (2000) yang menyatakan bahwa impulse buying merupakan keputusan yang emosional atau menurut desakan hati. Keputusan membeli yang tidak terencana sebelumnya dapat muncul karena pelanggan tertarik dengan promosi yang diberikan dirasa cocok, seperti cash back ,price discount, undian, hadiah, dan kupon.

Price discount merupakan promosi penjualan yang banyak digunakan, baik penjualan online maupun offline (Chen, Marmorstein, Tsiro, \& Rao,2012; Dawson \& Kim, 2009). Price discount adalah strategi promosi penjualan berbasis harga, ketika pelanggan ditawarkan produk yang sama dengan harga yang berkurang.

Berdasarkan hasil penelitian dari Kurniawan dan Yohanes (2013), terdapat pengaruh yang positif dan signifikan promosi terhadap impulse buying di Matahari department store cabang supermall Surabaya. Salah satu indikator dari promosi tersebut adalah price discount atau diskon harga. Semakin tinggi tingkat promosi, maka akan semakin tinggi pula keputusan impulse buying (Putri, 2014). Pernyataan tersebut jugadidukung oleh penelitian yang dilakukan oleh $\mathrm{Xu}$ et al. (2014) yang menyatakan bahwa diskon harga akan memicu niat membeli impulsif. Park (2006) dalam penelitiannya menyebutkan bahwa impulse buying dipengaruhi oleh beberapa hal, salah satunya pengalaman yang bersifat hedonik. Hal yang sama diungkapkan oleh Silvera et al. (2008) yang mengungkapkan bahwa kesenangan didorong karena pencapaian tujuan yang bersifat hedonik.

Hausman (2000) mengungkapkan bahwa nilai hedonik dapat dipuaskan dengan perasaan emosional yang timbul dari interaksi sosial yang diperoleh saat berbelanja. Tjiptono (2008) mengkategorikan diskon harga 
sebagai salah bentuk promosi penjualan. Parguel et al.(2007) juga memaparkan bahwa pengecer (retailer) menggunakan promosi penjualandalam berbagai cara yang intensif untuk menarik perhatian pelanggan danmeningkatkan penjualan. Terkait dengan nilai hedonik, Arnold dan Reynolds (2003)mengungkapkan jika harga diskon merupakan salah satu faktor yang dapat memotivasipelanggan untuk melakukan belanja hedonik. Artinya, pada kategori tersebut pelangganmelakukan aktivitas belanja untuk mendapatkan promosi penjualanmencari potongan tunai (diskon), dan harga termurah.

Pengertian minuman isotonik adalah cairan yang dibuat untuk dapat diminum dimana konsentrasi air dalam cairan intraselular adalah sama dan zat terlarut tidak dapat masuk atau keluar dari sel. Cairan isotonik adalah cairan yang konsentrasi atau kepekatannya sama dengan cairan tubuh, contohnya $\mathrm{NaCl}$ 0,9\%, larutan Ringer Lactate (RL).

Menurut buku kategori pangan BPOM RI 2006, definisi minuman isotonik adalah minuman formulasi yang ditujukan untuk menggantikan cairan, karbohidrat, elektrolit, dan mineral tubuh dengan cepat. Dengan demikian, minuman ini dapat diserap tubuh setelah diminum. Pada prinsipnya minuman isotonik ini untuk mencegah dehidrasi serta memberikan energi yang dapat digunakan dengan cepat.

Pertimbangan yang penting dalam membuat minuman isotonik adalah minuman harus mempunyai sifat-sifat mengosongkan perut dengan cepat dan penyerapan yang tinggi dalam usus. Selain itu, sifat ini dapat mempengaruhi fungsi jantung serta mengatur suhu tubuh, sehingga dengan demikian meningkatkan kinerja tubuh.Kedua sifat ini ditentukan oleh jumlah dan jenis karbohidrat yang terkandung dalam minuman isotonik serta faktor-faktor lainnya. (Winarti, 2006).

Atas dasar latar belakang dan penelitian terdahulu, penelitian ini melakukankajian tentang strategi seles promotion price discount dalam mendorong pembelian impulsif produk jenis minuman isotonik

\section{B. Metode Penelitian}

Metode penelitian adalah "cara-cara ilmiah untuk mendapatkan data yang valid, dengan tujuan dapat ditemukan, dikembangkan dan dibuktikan, suatu pengetahuan tertentu sehingga pada gilirannya dapat digunakan untuk memahami, memecahkan, dan mengantisipasi masalah" (Sugiyono, 2009:6)

Metode penelitian kulitatif adalah penelitian yang bermaksud untuk memahami fenomena tentang apa yang dialami oleh subjek penelitian secara holistik (utuh) dan dengan cara deskripsidalam bentuk kata-kata dan bahasa pada suatu konteks khusus yang alamiah, sertadengan memanfaatkan berbagai metode alamiah yang salah satunya bermanfaatuntuk keperluan meneliti dari segi prosesnya (Moleong, 2007: 6-7).

\section{Analisis dan Pembahasan}

PT.Amerta Indah Otsuka hamper tersebar di seluruh wilayah Lombok 
timur dan mengalami peningkatan setiap harinya, berarti strategi sales promosi yang digunakan berupa price discount sudah berhasil mendorong pembelian impulsif produk jenis minuman isotonik di PT. Amerta Indah Otsuka. Discount yang di berikan PT. Amerta Indah Otsuka kepada para konsumen termasuk dalam kategori sangat baik karena PT. Amerta Indah Otsuka sering memberikan discount dalam jangka waktu yang panjang, penawaran discountnya tidak tergantung pada event tertentu, barang yang di discount juga beragam, dan kualitasnya cukup baik. Sehingga konsumen merasa diuntungkan dengan adanya discount di PT. Amerta Indah Otsuka.

Hal ini diperkuat dengan hasil penelitian yang dilakukan peneliti ke beberapa toko, outlet, kios dan pelanggan PT. Amerta Indah Otsuka.

Sumber informasi dari informan pembeli langsung yang mengkonsumsi produk minuman isotonic yakni "Bapaka Wawan Suherman serang karyawan swasta di perusahaan yang beralamat di Dasan Selong" beliu berkata strategi yang di gunakan oleh PT. Amerta Indah Otsuka sudah bagus dengan adanya even diskon ini sangat efektif menarik minat konsumen utk membeli produk minuman isotonik, apalagi dengan kondisi tempat yang dipilih sudah tepat karena orang setelah berolahraga biasanya akan haus dan butuh minuman yang seger - seger seperti minuman isotonic ini. (Wawan Cara pada saat acara cup free day) Pendapat bapak wawan juaga diperkuat dengan pendapat Mariana, seorang mahasiswa dari Stekes Mataram menurunya diskon yang diberikan oleh PT. Amerta Indah Otsuka sangat menarik minat saya untuk membeli produk minuman isotonik yang dijual oleh PT. Amerta Indah Otsuka karena ini yang saya cari maklum keuangan mahasiswa pasti pingin cari yang ada diskon- diskon.

Melihat jawaban dari dua informan yang di wawancara maka peneliti dapat menyimpulkan strategi sales promotion price discount sudah efektip mendorong niat beli konsumen untuk membeli minuman isotonik untuk dikonsumsi sendiri.

Sumber imformasi dari pemilik autlet $\mathrm{Hj}$.Hamidah menurut beliu saya senang berlanggan di PT. Amerta Indah Otsuka dikarenakan banyak diskondiskon yang saya peroleh ketika saya membeli produk minuman jenis isotonik, jadi ketika saya jual lagi Alhamdulillah saya mendapatkan keuntungan lumanyan banyak dari harga beli, maka dari itu saya tidak mau berpaling berlangganan dari PT. Amerta Indah Otsuka walaupun banyak distributor-distributor yang dating menarkan saya produk yang sama (Wawan cara di Outlet) Sumber dari UD.Saefani menurut pemilik dia seneng berbelanja di PT. Amerta Indah Otsuka dikarenakan diskon yang diberikan setiap ada program pembelian barang diatas satu juta biasannya pihak PT. Amerta Indah Otsuka akan memberikan diskon berupa undian ataupun potongan harga barang.

\section{Kesimpulan}

Kesimpulan Berdasarkan hasil penelitian yang telah dilakukan, maka dapat disimpulkan:

1. Variabel discount dapat mendorong peningkatan impulse buying konsumen pada PT. Amerta Indah Otsuka. discount yang diberiakn mampu meningkatkan 
volume penjulan minuman jenis isotenik pada PT. Amerta Indah Otsuka. Berarti strategi seles promosi dengan menggunakan diskon sudah berhasil dan mampu menarik atau mempengaruhi minat beli masyarakat.

2. Disamping promosi seles diskon yang digunakan pihak PT. Amerta Indah Otsuka harus juga memperhatikan merchandising produknya Karen hal ini juga sangat berpengaruh terhadap keingin konsumen untuk mau berbelanja di PT. Amerta Indah Otsuka.

\section{Daftar Pustaka}

Amrullah, I. K. 2006. Nutrisi Ayam Broiler. Lembaga Satu Gunung Budi, Bogor

Atmomarsono. 2004. Upaya Menghasilkan Daging Broiler Aman dan sehat. Pidato Pengukuhan Guru Besar Dalam Ilmu Ternak. Fakultas Peternakan Universitas Diponegoro. Semarang.

Boediono. 1990. Ekonomi Moneter. Edisi Ketiga. Yogyakarta: BPFE-UGM.

Esminger, M.E. 1980. Poultry Scien (Animal Agriculture Series). 2nd Ed. The Publishing, Inc. Danville. Illionis.

Fadillah. R, 2007. Sukses Berternak Ayam Broiler. PT.Agromedia Pustaka:. Ciganjur.

Miller, J. K.; Brzezinska-Slebodzinska, E.; \& Madsen, F. C. Oxidative Stress, Antioxidants, And Animal Function. Journal of Dairy Science. 1993, 76(9), 2812-2823.

Mulyantini, N.G.A. 2010. Ilmu Manajemen Ternak Unggas. UGM Press. Hal: 33; 151; 163; 168-169. Yogyakarta.

Murtidjo. 1994. Pedoman Beternak Ayam Broiler. Aksi Agraris Kanisius

Rasyaf, M.1993. Beternak Ayam Pedaging. Cetakan kelima. Penebar Swadaya. Yogyakarta.

Santosa, P. B. dan Ashari. 2005. Analisa Statistik dengan Microsoft Excel dan SPSS. Penerbit ANDI, Yogyakarta.

Soekartawi. 1995. Analisis Usahatani. Universitas Indonesia Press. Jakarta

Sudaryani, T. Dan H. Santoso.1999. Pembibitan Ayam Ras. Cetakan keempat. Penebar Swadaya. Jakarta.

Sudaryani, T. dan H. Santosa. 1996. Pemeliharaan Ayam Ras Petelur di Kandang. Baterai. Edisi ke-1. PT. Penebar Swadaya. Jakarta. 
Jl. KH. Ahmad Dahlan No.1, Pagesangan, Kec. Mataram, Kota Mataram, Nusa Tenggara

Sudaryani, T dan Santoso, 2003. Pembibitan Ayam Ras. PT. Penebar Swadaya: Bogor

Suprijatna, E., Umiyati A. dan Ruhyat K. 2005. Ilmu Dasar Ternak Unggas. Cetakan I. Penebar Swadaya, Jakarta.

Yuwanta, 2004. Teknik Modern Beternak Ayam. Yasaguna, Jakarta . Universitas Sumatera Utara.

https://id.wikipedia.org/wiki/Ayam_broiler

www.pertanianku.com. 2016. Mengenal Sistem Kontrak Dalam Usaha Ayam Broiler. Artikel.

https:// Ayam Broiler $\mid$ Sejarah, Jenis-Jenis, Pakan, Hama \& Penyakit (duniabinatang.net) 